\section{P_021 縦隔原発悪性胚細胞腫瘍の治療}

\section{熊本市立熊本市民病院}

\section{馬場 憲一郎, 岡崎 伸治}

縱隔原発悪性胚細胞腫瘍 3 例を経験した。症例 $1 ： 22$ 歳, 男性. 精上皮腫でリンパ節転移，脈管浸襲を認めた。術後 CDDP + VLB， RT (放射線療法)。40力月，63力月後に 局所再発し再切除した. その後骨盤, 胸腹壁に再発をくり 返し，10年間 18 カ所に外来RTを行ったが 12 年目肝転移, 腹膜播種で死亡した。9 年目頃から AFP值が上昇し，治 療の指標となった。播種部の組織像は卵黄囊癌に類似し, RTによる精上皮腫の変異の可能性が示唆された。症例 2 : 26 歳, 男性. 混合性胚細胞腫瘍で術後にCDDP + VP16療法. 7 カ月後に局所再発した.PVB, PBSCT療法, $\mathrm{RT}, \mathrm{CDDP}+\mathrm{CPT}-11$ 療法を行い, 26 力月目に再切除し たが，32 力月後悪性心膜炎で死亡. 症例 3：41歳, 男性. 卵黄囊癌で術前にPVB，CDDP + V P - 16 療法 (AFP4491ng/mlから $130 \mathrm{ng} / \mathrm{ml}$ ) 後摘出術を行った。術後 2 週間後には心外膜部に再発し，56日目に死しした。結 語：縦隔原発の胚細胞腫瘍は術前合併療法による局所制御 が望ましい.AFP 值は胚細胞腫瘍の治療効果の指標とな る。 反応がそしい場合，予後は不良で手術適応はない
$\mathrm{P}-022$

術前化学療法後に完全切除しえた緥隔原発 悪性胚細胞性腫瘍の3 例

倉敷中央病院 呼吸器外科

奥村 典仁, 張 性洙, 河野 朋战, 小林 孝暢

最近われわれは稀な疾患である縦隔原発悪性胚細胞性腫瘍 に対し，末梢血幹細胞輸血（PBSCT）を伴う化学療法後 に完全切除できた 3 例を経験したので報告する.【症例 1】 38 歳男性. 検診発見で前縦隔腫瘍の診断を受けるも $\mathrm{HCG}-\beta$ 高值のため本疾患を疑い, CT ガイド下針生検施 行. 七ミノーマの診断を得, BEP3コース施行後に, 切除 施行. 切除腫瘍内にviable cellを認めず.【症例2】26歳男 性. 左胸部痛, 咳嗽にて発症の前縦隔腫瘍. AFP高值を 示し，CTガイド下針生検施行。悪性胚細胞腫の診断を得， BEP1コース, VIP2コース施行。この間PBSCT施行し, この後手術を施行. 組織診断の結果, 卵黄囊腫瘍で viable cellを一部に認められ，VIP2コースを追加.【症例 3】 29 歳男性. 咳嗽, 全身倦怠感にて発症. AFP高值を示LCT ガイド下針生検にて卵黄囊腫瘍の診断を得た。BEP1コー ス, VIP4コース施行. この間PBSCT 施行. この後手術施 行. 切除腫瘍内に viable cellを一部認め, VIP2 コース追 加.【結語】3例とも現在までに再発を認めていない。予 後不良とされる非セミノーマ型腫瘍に拈いても PBSCTを 組み合わせた十分な化学療法を併用することにより, 良好 な予後が期待できるものと考えられた。

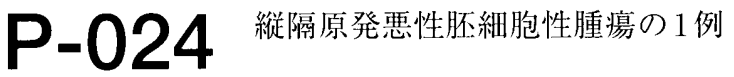

術前化学療法が奏功した縦隔原発卵黄囊腫 瘍の一切除例

${ }^{1}$ 岐皁大学 第一外科, ${ }^{2}$ 岐阜大学 臨床検査医学

白橋 幸洋', 丸井努', 岩田 尚', 梅田 幸生', 福本 行臣 ${ }^{1}$, 水野 吉雅 ${ }^{1}$, 高木 寿人!, 森 義雄 ${ }^{1}$, 広瀬一1, 下川 邦泰 $^{2}$

縦隔原発胚細胞腫瘍の治療は術前化学療法を含めた集学的 治療が標準となりつつある。術前化学療法が奏功した縦隔 原発卵黄豪腫瘍に対し，摘出術施行したので報告する。症 例は28歳の男性. 主訴は咳嗽。既往歴に特記すべきこと なし．2002年3月頃より咳嗽が出現し，4月からは石前胸 部痛も認めたため近医受診。胸部X線上前縦隔腫痬と診 断され当科入院となった. 胸部 CTでは前縦隔から右胸腔 内に進展する $12 \times 9 \mathrm{~cm}$ の腫瘤㓌影を認め，上大静脈を巻き 込み，肺との境界は不明膫であった。右上葉には散在する 結節影を認めた。入院時 AFP 值は $34550 \mathrm{ng} / \mathrm{ml}$ であった。 経皮的針生検にて卵黄囊腫瘍と診断された。化学療法 (CDDP，VP-16，Bleomycin)を4クール施行し，腫瘍は $8 \mathrm{x} 4 \mathrm{~cm}$ と縮小，AFP值は $4.6 \mathrm{ng} / \mathrm{ml}$ に改善した。同年 8 月 右開胸にて腫瘍摘出術，在上中葉切除術，上大静脈形成術 を施行した。腫瘍は上大静脈，右上中葉に強固に癒着して いた。化学療法 2 クール施行後退院となった. 術後 5 ケ月 の現在再発は無い. 病理診断は成熟奇形種で右上葉の結節, 上大静脈切除部にいずれも腫瘍細胞を認めなかった。
国立療養所兵庫中央病院 呼吸器外科

宮本 良文, 遠山一成, 迎山恭臣, 佐竹 信祐

肝転移を伴った非セミノーマ型悪性胚細胞性腫瘍の1例を 経験したので報告する。【症例】 31 才，男性。胸痛を主訴 に来院, 前縦隔に $8 \mathrm{~cm}$ の腫瘍が存在し, AFP $53.5 \mathrm{ng} / \mathrm{ml}$, $\mathrm{HCG} 25 \mathrm{mIU} / \mathrm{ml}$ と高值で, 肝臓に $3 \mathrm{~cm}$ 大の転移を認めた. 縦隔原発の非セミノーマ型悪性肧細胞性腫瘍と診断し, 化 学療法 (CDDP + VP-16 + BLM + DXR) を4クール施行 したところ, 腫瘍マーカーは正常化し, 原発巣, 肝転移と も著明に縮小したが, 約 3 ケ月後 AFPが再上昇し, 原発 巣の増大傾向を認めた. 肝転移巣に変化はなく, 縦隔原発 巣の摘出術を行ったところ，AFPは正常範囲内にまで低 下しした。病理診断の結果では, immature teratroma, embryonal carcinoma, choriocarcinomaの成分が認めら れた。術後化学療法（CDDP + PTX + IFM）を 2 クール 追加し, 2 年 6 ヶ月を経過した現在, 肝転移巣は消失して 健在である。【まとめ】縦隔原発悪性胚細胞性腫瘍の治療 にあたっては，化学療法と手術をタイミングよく組み合わ せることが肝要と考えられた。 